\title{
Alakohtainen vuorovaikutuskoulutus lääkärin, farmaseutin ja juristin professioissa
}

Pekka Isotalus, Sanna Ala-Kortesmaa, Maija Gerlander, Marja-Leena Hyvärinen, Jonna Koponen \& Tuula-Riitta Välikoski

\section{Tiivistelmä}

Vuorovaikutusosaamisen merkitys on kasvanut työelämässä lähes kaikilla aloilla. Työelämän vuorovaikutustilanteet tuovat uusia haasteita myös vuorovaikutuskoulutukselle. Puheviestinnän opettamisen kentällä on käyty keskustelua, miten asiantuntijoita tulisi opettaa, jotta heidän ammatillinen vuorovaikutusosaamisensa kehittyisi parhaalla mahdollisella tavalla. Alakohtainen viestintäpedagogiikka asettuu tähän keskusteluun tarjoamalla teoreettisen viitekehyksen ammatillisen ja alakohtaisen puheviestinnän opettamisen tarkasteluun. Aiemmissa tutkimuksissa alakohtaista vuorovaikutusosaamista on kuitenkin yleensä tarkasteltu vain yhden ammatin näkökulmasta. Tässä artikkelissa sovelletaan alakohtaisen viestintäpedagogiikan teoreettista viitekehystä kolmeen perinteiseen professioon, lääkärin, farmaseutin ja juristin ammattiin. Kutakin alaa tarkastellaan ensin erikseen alakohtaisen viestintäpedagogiikan keskeisten periaatteiden mukaisesti, minkä perusteella tehdään tapausten välinen analyysi. Tavoitteemme on vertailla, kuinka alakohtaisen viestintäpedagogiikan teoreettinen viitekehys soveltuu kolmen eri profession vuorovaikutuskoulutukseen. Vertailun perusteella nostamme esiin alakohtaista vuorovaikutuskoulutusta tukevia, mutta myös sitä kritisoivia argumentteja. Esitämme myös teoreettisia ja käytännöllisiä pohdintoja alakohtaisen viestintäpedagogiikan kehittämiseksi. Teoreettiset pohdinnat liittyvät alakohtaisen viestintäpedagogiikan viitekehyksen laajentamiseen. Käytännölliset pohdinnat kytkeytyvät alakohtaisen viestintäpedagogiikan soveltamiseen käytännön opetustyön tasolla. Alojen vuorovaikutuskoulutuksen vertailu kertoo myös puheviestinnän koulutuksen nykyisistä haasteista.

Asiasanat: alakohtainen viestintäpedagogiikka, farmaseutti, juristi, koulutus, lääkäri, vuorovaikutus 


\section{Johdanto}

Vuorovaikutuksen korostaminen on aikamme ilmiö, mikä näkyy monella eri elämän alueella. Esimerkiksi nykyiset oppimisnäkemykset korostavat vuorovaikutuksen merkitystä koulutuksessa. Terveydenhoidossa korostetaan potilaan asemaa ja asiakaslähtöisyyttä, jolloin alan ammattilaisen ja potilaan välinen vuorovaikutus nousee keskiöön. Yksi johtamisen trendeistä on vuorovaikutusjohtaminen. Oikeussalissa on siirrytty kirjallisesta käsittelystä suulliseen, mikä on tehnyt siitäkin vuorovaikutteisemman kontekstin. Poliitikoilta edellytetään kykyä olla vuorovaikutuksessa äänestäjiensä kanssa. Vuorovaikutteisen mobiiliteknologian sekä sosiaalisen median syntyminen ja kasvu on nostanut vuorovaikutuksen monella tavalla ihan uuteen asemaan, ja koko mediayhteiskunnassa vuorovaikutuksesta on muodostunut keskeinen käsite.

Vuorovaikutuksen korostuminen koko yhteiskunnassa heijastuu myös eri ammattialoille. Erityisen hyvin tämä näkyy siinä, että lähes kaikissa työpaikkailmoituksissa alasta riippumatta hakijalta edellytetään hyviä vuorovaikutustaitoja. Vuorovaikutus on keskeistä etenkin ns. ihmissuhdeammateissa, joissa suurin osa työstä tehdään viestintäsuhteissa erilaisten ihmisten kanssa (Gerlander \& Isotalus 2010).

Vuorovaikutusosaamista on lähestytty ja määritelty erilaisista näkökulmista (ks. Spitzberg \& Dillard 2002, Valkonen 2003). Tässä artikkelissa vuorovaikutusosaamisen (interpersonal communication competence) nähdään koostuvan vuorovaikutukseen liittyvistä tiedollisesta, taidollisesta ja affektiivisesta ulottuvuuksista, jotka ovat yhteydessä toisiinsa (Spitzberg \& Cupach 2002, 574). Vuorovaikutusosaaminen on viestintäkulttuuriin, -tilanteeseen ja -suhteeseen nähden tarkoituksenmukaista, tehokasta ja eettistä toimintaa, joka rakentuu ja määrittyy vuorovaikutuksen eri osapuolten yhteistyönä heidän vuorovaikutussuhteessaan. Vuorovaikutusosaamiseen liittyy olennaisesti myös osapuolten taito ennakoida, säädellä ja arvioida viestintäkäyttäytymistään. (Spitzberg \& Cupach 2002; Valkonen 2003.)

Tässä artikkelissa näemme vuorovaikutusosaamisen keskeisenä ammattiosaamisen ulottuvuutena. Tarkastelemme vuorovaikutusosaamista ja alakohtaista vuorovaikutuskoulutusta kolmessa professiossa, lääkärin, farmaseutin ja juristin ammatissa. Olemme valinneet nämä ammatit, koska ne ovat perinteisiä akateemiseen koulutukseen perustuvia professioita, joissa toimiminen edellyttää koulutuksessa saavutettua erikoisasiantuntemusta. Lisäksi valittujen ammattien vuorovaikutusta luonnehtii institutionaalisuus ja ongelmakeskeisyys. Niissä kaikissa ammattilainen pyrkii selvittämään ei-ammattilaisen ongelmaa - lääkäri potilaan ongelmaa, farmaseutti asiakkaan tarpeita ja lääkkeiden käyttöä ja juristi asiakkaan rikos-, riita- tai hakemusasiaa - ja etsimään sille ratkaisua. Toisaalta toiminnan luonne ja toimintaympäristö ovat niissä erilaisia. Näiden alojen asiantuntijan vuorovaikutusosaamisella voi olla myös suoria tai välillisesti jopa 
vakavia vaikutuksia kansalaisille, esimerkiksi terveyteemme tai juridiseen kohteluumme liittyen. Lisäksi työryhmässämme on kokemuksellista tietoa näiden ammattien vuorovaikutuskoulutuksesta

Puheviestinnän koulutuksessa on tukeuduttu useisiin erilaisiin teoreettisiin lähtökohtiin. Esimerkiksi koulutuksen taustalla on ollut kokemuksellinen ja reflektiivinen oppiminen (Kurtz, Silverman \& Draper 2005), sosiaalisen oppimisen teoria (Hargie 2006) sekä behavioristiseen oppimisnäkemykseen pohjaava vuorovaikutustaitojen harjoittelumalli (Dickson, Hargie \& Morrow 1991). Sen sijaan alakohtaisen viestintäpedagogiikan teoreettista viitekehystä on sovellettu puheviestinnän koulutukseen harvemmin (ks. Hyvärinen 2011; Koponen 2012). Kyseessä on kuitenkin yksi harvoista nimenomaan viestinnän koulutukseen kehitellyistä teoreettisista viitekehyksistä. Vaikka meillä on runsaasti tutkittua tietoa vuorovaikutuskoulutuksen vaikuttavuudesta sekä toteuttamis- ja arviointitavoista (Aspegren 1999; Hargie ym. 2010), ei aiemmissa tutkimuksissa ole juurikaan vertailtu vuorovaikutuskoulutuksen alakohtaisia erityispiirteitä. Lisäksi alakohtaisen viestintäpedagogiikan teoreettista viitekehystä on tarkasteltu aikaisemmin vain yhdessä ammatissa kerrallaan. Näin ollen tässä tutkimuksessa tavoitteenamme on vertailla, kuinka alakohtaisen viestintäpedagogiikan teoreettinen viitekehys soveltuu kolmen eri profession vuorovaikutuskoulutukseen. Näin tutkimme, mitä teoreettisia ja käytännöllisiä kysymyksiä eri alojen ristivalottaminen asettaa alakohtaiselle viestintäpedagogiikalle. Vertailumme perusteella esitämme käytännöllisiä ja teoreettisia pohdintoja alakohtaisen viestintäpedagogiikan kehittämiseksi. Pohdimme alakohtaisen viestintäpedagogiikan soveltamista käytännön opetustyön tasolla sekä sen teoreettiseen laajentamiseen liittyviä kysymyksiä. Nostamme artikkelissa esiin alakohtaista vuorovaikutuskoulutusta tukevia, mutta myös sitä kritisoivia argumentteja.

\section{Alakohtainen viestintäpedagogiikka}

Alakohtainen puheviestinnän opetus ja viestintäpedagoginen teoriatausta ovat nousseet puheviestintätieteelliseen keskusteluun ja tutkimukseen 2000-luvun alkupuolella, jolloin Deanna Dannels (2001) peräänkuulutti uutta menetelmällistä ja pedagogista teoriataustaa alakohtaiseen ja ammatillisesti suunnattuun vuorovaikutuskoulutukseen. Alakohtaisen viestintäpedagogiikan (communication in the disciplines) nimellä tunnettu suuntaus voidaan Dannelsin (2001) mukaan tiivistää seuraaviin pääkohtiin: 1) kunkin alan vuorovaikutusosaamisen vaatimukset määritellään alakohtaisesti, 2) alakohtainen vuorovaikutusosaaminen opitaan vähitellen tilanteissa, joissa yksilö osallistuu alansa asiantuntijayhteisöjen toimintaan, 3) oppiminen on tilannesidonnaista ja sosiaalista toimintaa ja 4) vuorovaikutusosaamisen arvioinnissa tulee ottaa huomioon alakohtaiset erityisvaatimukset ja kriteerit. 
Alakohtaisen viestintäpedagogiikan mukaan ensinnäkin kukin ala itse määrittelee, mitkä vuorovaikutustilanteet ovat alalla keskeisiä, millaista vuorovaikutusosaamista niissä tarvitaan ja millaista viestintää pidetään tilanteeseen ja tarkoitukseen sopivana. Tämä perustuu näkemykseen vuorovaikutusosaamisen kiinteästä yhteydestä alasidonnaisiin arvoihin, arvostuksiin, odotuksiin, normeihin ja hyväksyttyihin käytänteisiin (Dannels 2001). Se, mitä jollakin alalla pidetään tehokkaana ja tarkoituksenmukaisena toimintatapana, ei välttämättä päde toisella alalla. Siksi on tärkeää, että vuorovaikutusosaamisen erityispiirteet tunnistetaan ja jäsennetään alakohtaisesti.

Toinen alakohtaisen viestintäpedagogiikan kantavista ajatuksista liittyy vuorovaikutusosaamisen oppimiseen. Alan ja ammatin kannalta merkityksellistä osaamista opitaan alalle ominaisissa yhteisöllisissä prosesseissa, joissa luodaan yhteisiä merkityksiä ja ymmärrystä alan osaamisvaatimuksista. Keskeisiä oppimisessa ovat genret, joilla alakohtaisessa viestintäpedagogiikassa tarkoitetaan tiettyjä alalle tyypillisiä vuorovaikutuskonteksteja. Ne vaikuttavat tilanteeseen osallistuvien tapaan tuottaa ja tulkita viestintäkäyttäytymistä (Dannels 2001; Miller 1984). Tyypillisiä alakohtaisia genrejä ovat esimerkiksi tavat haastatella potilaita ja todistajia. Alakohtaisessa puheviestinnän opetuksessa tulisi näin ollen selvittää, millaiset puhumisen genret ovat opetettavalle alalle keskeisiä, mitä erityispiirteitä niihin liittyy ja millaisiin puhumisen genreihin oppiminen voitaisiin yhdistää. Näin opiskelija saisi mahdollisuuden jäsentää ja oppia alalla tarvittavaa vuorovaikutusosaamista.

Kolmas alakohtaisen viestintäpedagogiikan pääperiaatteista liittyy näkemykseen oppimisen tilannesidonnaisesta luonteesta. Näkökulman taustalla on oppimisen tilannesidonnaisuutta edustavat teoriat, kuten Laven ja Wengerin (1991) esittämät ajatukset oppimisesta sosiaalisena osallistumisena. Oppimista ei niinkään tarkastella yksilön kognitiivisena toimintana, vaan pikemminkin oppiminen liitetään kiinteästi oppimistilanteeseen ja siihen osallistuvien ihmisten keskinäiseen vuorovaikutukseen ja vuorovaikutuksen avulla syntyviin oppimistuloksiin. Oppiminen ymmärretään eräänlaisena sosiaalistumisena tietylle alalle ja tiettyyn kulttuuriin, minkä vuoksi oppimisen tulisi olla kiinteässä yhteydessä opiskeltavaan alaan, ammattiin ja siihen tilanteeseen, jossa opittua käytetään (ks. Dannels 2001; Lave \& Wenger 1991). Esimerkiksi oppilaitoksissa tapahtuvien opetus- ja oppimisprosessien haasteet liittyvät juuri siihen, etteivät ne välttämättä vastaa sitä käyttöyhteyttä, jota varten ollaan oppimassa. Vaikka opetuksessa pyrittäisiin luomaan kiinteä yhteys työelämän käytänteisiin, on Dannelsin (2001) mukaan hyvin todennäköistä, että opiskelijat oppivat herkästi sellaisia toimintatapoja, joita kyseisessä opetuskontekstissa arvostetaan.

Neljänneksi, koska alakohtainen viestintäpedagogiikka katsoo vuorovaikutusosaamista kiinteässä yhteydessä kunkin alan sisäisiin erityisvaatimuksiin, myös osaamisen arvioinnin tulisi perustua alakohtaisille kriteereille. Silti ei ole juuri tehty tutkimusta, jossa tarkasteltaisiin tietylle alalle relevantin vuorovai- 
kutusosaamisen saavuttamista vuorovaikutuskoulutuksen tuloksena (Dannels 2001). Tähänastinen alakohtaisen viestintäpedagogiikan tutkimus on keskittynyt lähinnä tunnistamaan erilaisia alasidonnaisia vuorovaikutuskonteksteja ja näissä konteksteissa tarvittavia vuorovaikutustaitoja esimerkiksi teknisillä aloilla (Darling 2005), kauppatieteissä (Tuleja \& Greenhalgh 2008) sekä ravitsemustieteen (Vrchota 2011), muotoilun (Morton \& O’Brien 2005) ja lääketieteen aloilla (Haber \& Lingard 2001). Seuraavaksi tarkastelemme alakohtaista vuorovaikutuskoulutusta aikaisempaan kirjallisuuteen nojautuen lääkärin, farmaseutin ja juristin ammateissa.

\section{Lääkärin vuorovaikutusosaaminen ja sen opettaminen}

Lääkärin ammatti on perinteinen professio, jonka päämääränä on terveyden ylläpitäminen ja edistäminen, sairauksien ehkäiseminen sekä sairaiden parantaminen ja heidän kärsimystensä lievittäminen (Saarni 2005). Suomessa laki potilaan asemasta ja oikeuksista (785/1992) velvoittaa lääkäriä tekemään potilasta koskevat hoitopäätökset yhteisymmärryksessä potilaan kanssa. Yhteisymmärrykseen pääsemisessä tarvitaan sekä lääketieteellistä osaamista että taitoa olla vuorovaikutuksessa potilaiden kanssa. Viime aikoina onkin korostettu, että lääkärin työssä menestymiseen ei riitä pelkästään lääketieteellisen tiedon hallinta ja kliininen osaaminen vaan työssä tarvitaan olennaisesti vuorovaikutusosaamista (Palsson ym. 2007).

Lääkärin ja potilaan kohtaamisia tapahtuu vuosittain miljoonia ja on arvioitu, että kliinisessä työssä toimiva lääkäri tekee työuransa aikana keskimäärin 60 000-100 000 potilashaastattelua (Saha 2003, 20). Vuorovaikutusosaaminen auttaa lääkäriä työn tavoitteiden saavuttamisessa. Useissa tutkimuksissa on osoitettu, että lääkärin ja potilaan välisen vuorovaikutuksen onnistuminen on yhteydessä potilaan kokemaan hoitotyytyväisyyteen, hoito-ohjeiden ymmärtämiseen ja muistamiseen, hoitomyöntyvyyteen, hoitotuloksiin, potilasvalitusten vähenemiseen sekä lääkärin työssä jaksamiseen (esim. Brown, Steward \& Ryan 2003; Street 2003). Toisaalta huonosti toimiva vuorovaikutus on keskeinen potilasvalitusten syy ja vuorovaikutuksen epäonnistuminen voi johtaa jopa hoitovirheisiin (Brown, Steward \& Ryan 2003).

\section{Vuorovaikutusosaaminen lääkärin ammatissa}

Suomessa ei ole yhteneväisesti määritelty, millaista vuorovaikutusosaamista vastavalmistuneelta lääketieteen lisensiaatilta vaaditaan (Koponen 2012). Viimeisin Lääkärikysely (2009) kuitenkin osoittaa, että suomalaiset lääkärit kokevat vuorovaikutus- ja yhteistyötaidot tärkeiksi työssä vaadittaviksi taidoiksi. Vuorovaikutustaitojen tarve koetaan suurimmaksi yleislääketieteessä ja psykiatriassa ja vähäisimmäksi ortopediassa ja radiologiassa. Toimialueista vuorovaikutustaitoja tarvitaan eniten terveyskeskuksissa ja työterveyshuollossa. Tästä 
voidaan päätellä, että lääkäreiden vuorovaikutusosaamisen tarpeet vaihtelevat työtehtävän ja aseman mukaan, ja ne näyttävät muuttuvan uran edetessä. Esimerkiksi erikoistuminen ja eteneminen johtotehtäviin vaikuttavat siihen, millaisen painoarvon ja merkityksen kukin vuorovaikutuskonteksti arkipäivän työssä saa.

Kansainvälisesti läkärin työssä tarvittavaa vuorovaikutusosaamista on jäsennetty lääkärin perustutkinnon osaamistavoitteissa (General Medical Council 2009; Hargie ym. 2010), kansainvälisissä lausunnoissa (Kalamazoo Consensus Statement 2001) sekä lääketieteen vuorovaikutuskoulutuksen lähtökohtana käytetyissä malleissa (ks. esim. Kurtz, Silverman \& Draper 2005). Useimmiten lääkärin vuorovaikutusosaamista on jäsennetty lääkäri-potilasviestinnän näkökulmasta vastaanoton vaiheiden mukaan. Tärkeimmiksi lääkärin tarvitsemiksi vuorovaikutustaidoiksi on nimetty potilashaastatteluun liittyvät vuorovaikutustaidot (Kalamazoo Consensus Statement 2001), kuten kuunteleminen, kysymysten esittäminen, nonverbaalisen viestinnän hallinta, informaation jäsentäminen ja selventäminen, ymmärrettävän kielen käyttäminen, sekä potilaan osallistaminen hoidon suunnitteluun ja yhteiseen päätöksentekoon. Osa lääkärin vuorovaikutusosaamisen jäsennyksistä korostaa myös vuorovaikutusta eri kohderyhmien kanssa ja nostaa esiin tiimi- ja yhteistyötaitojen merkityksen lääkärin työssä. Lääketieteen alalla keskeisenä pidetään myös vuorovaikutusosaamisen affektiivisen ulottuvuuden hallintaa, kuten motivaatioon ja asenteisiin liittyviä tekijöitä. Erityisesti korostetaan myönteisten ja potilaskeskeisten asenteiden merkitystä lääkärin työn onnistumisen näkökulmasta. (General Medical Council 2009.)

\section{Vuorovaikutuskontekstit lääkärin työssä}

Lääkärin työhön liittyy monenlaisia vuorovaikutustilanteita eri työskentelysektoreilla, mikä korostaa useiden erilaisten vuorovaikutuskontekstien merkitystä lääkärin työssä. Lääkärin ammatissa tärkeitä vuorovaikutuskonteksteja ovat esimerkiksi hoitotilanteet potilaiden kanssa, esiintymistilanteet, johtaminen sekä työskentely moniammatillisissa ja kollegiaalisissa tiimeissä (Dickson ym. 1991). Näistä tutkituin konteksti on lääkäri-potilasviestintä lääkärin vastaanotolla, mikä on usein nähty myös lääkärin työn ytimenä (Koponen 2012; Pyörälä \& Hietanen 2011). Myös esiintymiskontekstista lääkärin työssä on tehty alakohtaiseen viestintäpedagogiikkaan perustuvaa tutkimusta (Lingard ym. 2003). Lisäksi kulttuurienvälinen viestintä, viestintäteknologian kehittyminen ja erityistilanteiden monimuotoistuminen tuovat omat erityispiirteensä lääkärin työn vuorovaikutuskonteksteihin (Koponen 2012).

\section{Vuorovaikutusosaamisen oppimisen tilannesidonnaisuus ja sosiaalisuus}

Alakohtaisen viestintäpedagogiikan mukaan vuorovaikutuskoulutus tulisi järjestää tilanteissa, jotka ovat kunkin ammatin kannalta keskeisiä. Lisäksi vuorovaikutuskoulutuksen tulisi mahdollistaa keskustelu osallistujien ja opettajien 
kesken. Lääkärin työn näkökulmasta tämä tarkoittaa, että esimerkiksi potilashaastattelua olisi tarkoituksenmukaista harjoitella aidoissa tai mahdollisimman aidon kaltaisissa vuorovaikutustilanteissa oikeiden tai simuloitujen potilaiden kanssa. Oppiminen tulisi myös sitoa osaksi asiantuntijayhteisön toimintaa, mikä lääketieteen opiskelijoiden koulutuksessa onnistuukin varsin hyvin, sillä kliinisen vaiheen opiskelu perustuu siihen, että opiskelijat ovat osa sairaalayhteisöä ja oppivat kliinisiä taitoja yhdessä asiantuntijoiden kanssa (Pyörälä \& Hietanen 2011). Opiskelijat osallistuvat asteittain asiantuntijayhteisön toimintaan ja taitojen karttuessa he saavat enemmän valtuuksia osallistua potilaan hoitoon. Tällaisen pedagogisen järjestelyn voidaan nähdä olevan linjassa alakohtaisen viestintäpedagogiikan periaatteiden kanssa.

\section{Vuorovaikutusosaamisen arviointi lääketieteen alalla}

Lääketieteen alalla on kehitetty runsaasti erilaisia arviointimittareita vuorovaikutusosaamisen luotettavaa ja objektiivista arviointia varten (Hullman \& Daily 2008). Alalle tyypillisissä arviointimenetelmissä lääketieteen opiskelija tai asiantuntija toteuttaa potilashaastatteluharjoituksen simuloidun tai oikea potilaan kanssa. Vuorovaikutuksen onnistumista ja lääkärin vuorovaikutustaitoja arvioi ulkopuolinen havainnoija standardoidun ja validin arviointiasteikon avulla. Tyypillistä on myös, että opintojen loppuvaiheessa olevien lääketieteen opiskelijoiden vuorovaikutustaidot arvioidaan näyttötentissä (OSCE-tentti). Näyttötentillä ja vuorovaikutustaitojen numeerisella arvioinnilla on pyritty siihen, että lääketieteen opiskelijat suhtautuisivat vakavasti vuorovaikutustaitojen harjoitteluun ja että lääketieteelliset tiedekunnat oppisivat arvostamaan vuorovaikutuskoulutusta tärkeänä osana lääkäreiden peruskoulutusta. (Kurtz, Silverman \& Draper 2005.)

Alakohtaisen viestintäpedagogiikan teoreettisen viitekehyksen näkökulmasta lääketieteen alalla runsaasti käytettyjä arviointimenetelmiä voidaan myös kritisoida, sillä niissä arviointi kohdistuu suurimmaksi osaksi vain yksilön (lääkärin tai lääketieteen opiskelijan) vuorovaikutusosaamisen arviointiin. Koska alakohtainen viestintäpedagogiikka painottaa oppimisen sosiaalisuutta, voitaisiin arvioinnissa kiinnittää huomiota yksilön vuorovaikutusosaamisen lisäksi vuorovaikutusprosesseihin, potilaan kokemuksiin ja professionaalisen viestintäsuhteen laatuun.

\section{Farmaseutin vuorovaikutusosaaminen ja sen opettaminen}

Farmaseutit työskentelevät avohuollon apteekin asiakaspalvelutehtävissä, minkä lisäksi he sijoittuvat sairaaloiden ja terveyskeskusten apteekkeihin, lääkekeskuksiin, lääketeollisuuteen ja yliopistoihin (Anderson 2002). Tässä artikkelissa rajaamme tarkastelun avohuollon apteekeissa toimiviin farmaseutteihin, joiden vastuulla on asiakkaiden terveyteen ja sairaudenhoitoon liittyvä neuvonta 
sekä lääkehoidon ohjaus (International Pharmaceutical Federation 2004; World Health Organisation 2011). Heidän tehtävänään on edistää lääkkeiden oikeaa ja turvallista käyttöä ja estää niiden väärinkäyttöä. Keskeisenä tavoitteena on asiakkaiden terveyden edistäminen sekä hoidon seuranta ja tukeminen yhteistyössä muun terveydenhuollon kanssa. (Suomen Apteekkariliitto ja Suomen Farmasialiitto 1998.) Tehtävän vastuullisuus on erityisen korostunut itsehoidossa, koska farmaseutti voi olla ainoa terveysalan ammattilainen, jonka tietoa tarvitseva asiakas kohtaa (Sosiaali- ja terveysministeriö 2011).

Useat tutkimukset osoittavat, että farmaseutin ja asiakkaan välisen vuorovaikutuksen onnistumisella on merkittävä yhteys työn välittömiin ja välillisiin hoitotuloksiin, kuten esimerkiksi asiakkaan motivaatioon, tyytyväisyyteen, oikean hoidon valintaan, hoito-ohjeiden noudattamiseen, hoidon seurantaan ja lääkehaittojen ehkäisemiseen (Katajavuori ym. 2002; World Health Organisation 2011). Esimerkiksi suomalaisille tyypillisten kansansairauksien, kuten verenpaineen, astman ja diabeteksen kohdalla, asiakkailla on todettu lukuisia lääkehoitoihin liittyviä ongelmia, joihin apteekeissa voitaisiin tehokkaasti puuttua (Jokisalo 2005; Lahnajärvi 2006). Myös itsehoidossa on havaittu, etteivät asiakkaat osaa välttämättä tehdä oikeita lääkevalintoja ilman ammattilaisen apua (Suomen Apteekkariliitto 2011). Siksi on tärkeää, että farmaseutit osaavat tarjota neuvontaa aktiivisesti ja uskaltavat tarttua asiakkaiden terveysongelmiin ja valintoihin.

\section{Vuorovaikutusosaaminen farmaseutin ammatissa}

Farmaseutin vuorovaikutusosaamisen kuvauksia on runsaasti. Pääsääntöisesti osaamista kuvataan vuorovaikutustaitoina, joita on jäsennetty asiakasneuvontaa koskevien selvitysten, kampanjoiden ja tutkimusten yhteydessä sekä kansallisesti että kansainvälisesti (esim. Bzowyckyj \& Janke 2013; Puumalainen 2005), oppilaitokset ovat tuottaneet omia luokituksiaan (esim. Hyvärinen ym. 2012; Kimberlin 2006) tai osaamiskuvaukset perustuvat aihetta käsittelevien tutkimusten meta-analyysiin (Shah \& Chewning 2006). Yksi tunnetuista on useiden eri terveydenhuollon ja farmasian koulutusyksiköiden käyttämien perusrunkojen pohjalta kehitetty United States Pharmacopeian (2002) neuvonnan prosessimalli. Se kiinnittää huomiota vuorovaikutustaitoihin neuvonnan eri vaiheissa, joita ovat aloitus, sisältö ja päättäminen.

Kokonaisuutena tarkastellen osaamiskuvaukset ovat varsin yhteneväisiä (Wallman, Vaudan \& Kälvemark Sporrong 2013). Asiakaskeskeisyyttä ja keskustelemista sekä suhteen luomisen tärkeyttä korostetaan useimmissa kuvauksissa (Hyvärinen 2011). Myös kysymistä, kuuntelemista ja asiakkaan tarpeista lähtevää tiedon välittämistä pidetään tärkeänä. Esimerkiksi farmaseuttien ja tutkijoiden yhteistyönä syntynyt jäsennys pitää keskeisenä neuvonnan aloittamista, asiakassuhteen luomista, assertiivisuutta sekä kysymisen, kuuntelemisen, selittämisen, nonverbaalisen viestinnän, ehdotusten/vinkkien antamisen, 
avoimuuden, henkilökohtaisista asioista kertomisen, suostuttelun sekä tilanteen päättämisen taitoja (Hargie, Morrow \& Woodman 2000). Kuvauksille tyypillisenä piirteenä voidaan pitää viestinnän relationaalisen ulottuvuuden painottamista, eli osaamisvaatimuksissa korostetaan halua, kykyä ja rohkeutta luoda ja ylläpitää asiakkaiden aikaisempiin kokemuksiin, tarpeisiin ja odotuksiin perustuvia vuorovaikutussuhteita (Hyvärinen 2011; Shah \& Chewning 2006). Myös yhteistyö terveydenhuollon verkostoissa ja vaikuttaminen nähdään entistä tärkeämpinä osaamisalueina (Bzowyckyj \& Janke 2013).

\section{Vuorovaikutuskontekstit farmaseutin työssä}

Toisin kuin esimerkiksi lääkäreiden kohdalla farmasian alan tutkimus näyttää keskittyneen paljolti farmaseutti-asiakasvuorovaikutukseen eikä alalla ole välttämättä saavutettu konsensusta muista konteksteista ja niissä vaadittavasta osaamisesta (Bzowyckyj \& Janke 2013). Esimerkiksi työyhteisön sisäiseen viestintään tai terveydenhuollon yhteistyöverkostojen toimintaan osallistumista pidetään tärkeinä, mutta niitä koskevaa alakohtaista tutkimusta on vähemmän (Wallman, Vaudan \& Kälvemark Sporrong 2013). Avohuollon apteekissa keskeisin vuorovaikutuskonteksti on asiakaspalvelutilanne joko reseptillä lääkkeittään hakevan tai itsehoidossa asioivan asiakkaan ja farmaseutin kesken. Alalle on tuotettu runsaasti asiakasneuvontaa tukevaa materiaalia, ohjeita, kehittämishankkeita ja koulutusta (Kansanaho 2005; Vainio 2004), mikä korostaa tehtävän keskeisyyttä. Lisäksi tutkimuksista voidaan päätellä (Hyvärinen 2011; Wallman, Vaudan \& Kälvemark Sporrong 2013), että yksi merkittävä alakohtainen vuorovaikutuskonteksti on opiskelijan tutkintoon sisältyvä työharjoittelu, jonka yhteydessä sekä ammatissa toimivat farmaseutit että opiskelijat jäsentävät työnsä osaamisvaatimuksia ja kehittävät toimintaansa asiantuntijayhteisönä.

\section{Vuorovaikutusosaamisen oppimisen tilannesidonnaisuus ja sosiaalisuus}

Farmaseutin tutkinnosta merkittävä osa suoritetaan työharjoittelujaksoilla, minkä vuoksi ammattilaisten rooli opiskelijoiden osaamisen kehittämisessä on korostunut. Työpaikan erilaiset vuorovaikutustilanteet antavat opiskelijalle mahdollisuuden kasvaa asiantuntijayhteisön jäseneksi ja oppia alakohtaisia käytänteitä. Tutkimustiedon valossa opiskelijoiden työssä oppiminen ei ole kuitenkaan ongelmatonta, sillä apteekeissa ei ole välttämättä totuttu keskustelemaan alalla vaadittavasta osaamisesta eikä jakamaan hyviä käytänteitä (Hyvärinen 2011). Tästä syystä farmasian opiskelijoita tulisi rohkaista nykykäytänteiden kriittiseen problematisointiin ja jatkuvaan kehittämiseen, mikä on yksi alakohtaisen viestintäpedagogiikan tärkeistä tehtävistä. Esimerkiksi Hyvärisen (2001) tutkimus osoitti, että työelämään yhdistetyt vuorovaikutusharjoitukset tukevat sekä opiskelijoiden että heidän harjoitteluaan ohjaavien farmaseuttien molemminpuolista oppimista ja uudenlaisten työtapojen kehittämistä. 


\section{Vuorovaikutusosaamisen arviointi farmasian alalla}

Vaikka farmaseuttien työhön on tuotettu runsaasti asiakasneuvontaa kuvaavia malleja ja jäsennyksiä, arviointikäytänteet ovat Wallmanin ym. (2013) mukaan yhä hyvin hajanaisia ja yksipuolisesti opiskelijan itsearviointiin perustuvia. Lisäksi on havaittu, että käytössä olevat arviointikäytänteet saattavat ohjata liian kapea-alaiseen mallista oppimiseen ja yksipuoliseen asiantuntijan toiminnan tarkasteluun (Shah \& Chewning 2006). Alalla tehdyt tutkimukset ovat kuitenkin rohkaisevia, sillä arviointikriteereiden systemaattinen käyttö ohjaa arvioimaan oppimistuloksia suhteessa työelämän vaatimuksiin ja niitä voitaisiin hyödyntää myös esimerkiksi opiskelijan kehittymisen seuraamisessa (Hyvärinen 2011). Aivan kuten lääkäreiden vuorovaikutuskoulutuksessa, myös farmasian alalla tarvitaan arviointimenetelmiä, jotka ohjaavat suhdekeskeiseen ajatteluun ja toimintaan sekä asiakkaan kokemuksen ja vuorovaikutussuhteen laadun tarkasteluun.

\section{Juristin vuorovaikutusosaaminen ja sen opettaminen}

Oikeustieteen ylemmän korkeakoulututkinnon suorittanut juristi voi toimia esimerkiksi pankkilakimiehenä, hallintojuristina tai syyttäjänä. Tässä artikkelissa keskitymme syyttäjän ja tuomarin tehtäviin rikosoikeudenkäynnissä, jossa vuorovaikutusosaaminen on merkittävässä asemassa (Ala-Kortesmaa \& Välikoski 2008; Tirronen 2013). Suomessa toteutettiin erityisesti 90-luvulla laajoja oikeudenkäyntimenettelyä koskevia uudistuksia. Uudistusten yhtenä keskeisenä tavoitteena oli tehdä oikeudenkäynneistä välittömiä ja suullisia, jolloin niiden vuorovaikutus ja viestinnällinen luonne nousivat aiempaa keskeisemmäksi (Haavisto 2002; Välikoski 2004). Julkisuusperiaatteen mukaisesti pyrittiin avaamaan esimerkiksi rikosasioiden oikeudenkäyntimenettelyä, jotta oikeudenkäynnin tavoitteet, sisällöt ja oikeudenkäynnissä syntyvät ratkaisut avautuisivat myös oikeudenkäyntien maallikko-osapuolille (ks. HE 82/1995vp).

\section{Vuorovaikutusosaaminen oikeudenkäynnissä}

Oikeustieteen alan erilaisissa työtehtävissä tarpeellista vuorovaikutusosaamista on tutkittu jonkin verran (mm. Haavisto 2002; Välikoski 2000; 2004; Ala-Kortesmaa \& Välikoski 2008; Tirronen 2013). Juristin tehtävässä painottuu vuorovaikutusosaamisen kognitiivinen ulottuvuus, joka näkyy esimerkiksi taitona argumentoida nopeasti tai esittää olennaisia kysymyksiä todistajakuulustelussa. Todistajakuulustelussa keskeistä on myös vuorovaikutusosaamisen relationaalinen ulottuvuus, koska todistaja voi olla vaikkapa peloissaan tai jännittynyt (Välikoski 2000). Syyttäjät eivät kuitenkaan itse tätä relationaalista ulottuvuutta osaamisessaan painota (Välikoski \& Ala-Kortesmaa 2013). Valmistellessaan asioita oikeudenkäynnissä esitettäväksi juristit ovat tekemisissä paitsi kollegoidensa myös eri asiantuntijoiden ja viranomaisten kanssa. Tällöin- 
kin erilaiset yhteistyötaidot ovat erittäin keskeisiä (Ala-Kortesmaa \& Isotalus 2012). Alan erityisvaatimuksia sekä vuorovaikutusosaamisen kriteereitä ei ole Suomessa juuri määritelty. Sen sijaan esimerkiksi Yhdysvalloissa tärkeimmiksi on havaittu muun muassa esitutkinnassa tapahtuva kuulustelu, valamiehistön valintahaastattelu, neuvottelut asiakkaan kanssa, ristikuulustelu, loppulausunto, suullinen argumentointi ja oikeussalissa tapahtuva nonverbaalinen viestintä (Smith 1999). Myös Suomessa vuorovaikutus on erilaista istunnon eri vaiheissa ja oikeudenkäynnissä aktualisoituvissa erilaisissa rooleissa. Esimerkiksi riitaasian valmisteluistunto ja sovittelumenettely ovat viestintätilanteina istunnon puheenjohtajan tavoitteellista ryhmäviestintä- ja neuvotteluosaamista vaativia, kun taas rikosasian istuntokäsittelyssä vetovastuussa olevan syyttäjän vuorovaikutusosaaminen on olennaista.

Tehokas kuunteleminen on keskeinen osa juristin vuorovaikutusosaamista (Ala-Kortesmaa, Välikoski \& Isotalus 2011; Speicker \& Worthington 2008). On havaittu, että viestijän kuuntelemiskäsitykset ovat yhteydessä hänen vuorovaikutusorientaatioonsa (Ramburuth \& Mladenovic 2004). Tutkimustiedon perusteella oikeudenkäynnissä suomalainen juristi keskittyy kuunnellessaan faktoihin, käyttää tarkentavia kysymyksiä ja nonverbaalista viestintää osoittamaan kuuntelemistaan. Kuunteleminen ymmärretään subjektiivisena, yksilöllisenä toimintana. (Ala-Kortesmaa \& Välikoski 2008.) Toisaalta on tunnistettu, että esimerkiksi syyttäjä jättää viestinnän relationaalisen ulottuvuuden sekä kuuntelemisessaan että viestinnässään lähes huomiotta (Ala-Kortesmaa \& Välikoski 2009). Istuntosalissa on syyttäjän kuunteleminen vahvasti ns. asiakuuntelemista, joka liittyy oikeudellisen tehtävän hoitamiseen. Suomessa arvostetaan perinteisesti asiapuhetta, joten asiakuuntelemisella on selkeät juuret ammatillisessa vuorovaikutuksessa (Ala-Kortesmaa \& Isotalus 2012). Myös tarkoituksenmukaisen informaation saamisen kannalta toimiva vuorovaikutussuhde on kuitenkin välttämätön (ks. Speicker \& Worthington 2008).

\section{Vuorovaikutuskontekstit juristin työssä}

Tietyt puhumisen genret rakentuvat professiossa, ja ne opitaan kyseistä työtä seuraamalla. Näin tapahtuu myös oikeustieteen opinnoissa, joissa opiskelijat seuraavat tuomioistuinkäsittelyä prosessioikeuden kurssin osana. Esimerkiksi tuomioistuinkäsittelyn etenemisen vaiheet tuottavat selkeät puhumisen toimintamallit, mutta näitä malleja ei varsinaisesti opeteta, vaikka käsittelyn vaiheita opetetaankin. Niin sanotuissa common law -järjestelmän maissa, kuten Yhdysvalloissa ja Englannissa, joissa lainkäyttö perustuu oikeuskäytäntöön (Heathcote 2000), vuorovaikutuskoulutus limittyy luontevasti juristien peruskoulutukseen. Opiskelijoille tarjottavat kurssit lähestyvät oikeussaliviestintää useasta eri näkökulmasta ja antavat mahdollisuuden sekä kognitiiviseen että toiminnalliseen, työtehtäviin yhdistettyyn oppimiseen (Smith 1999). 


\section{Vuorovaikutusosaamisen oppimisen tilannesidonnaisuus ja sosiaalisuus}

Oikeudenkäyntiemme vahvasti kirjalliseen viestintään nojaava tausta on vaikuttanut siihen, että Suomessa oikeustieteen opinnoissa vuorovaikutusosaamista ei vieläkään runsaasti opeteta. Laajuus ja sisällöt vaihtelevat pakollisesta puheviestinnän peruskurssista vapaavalintaisiin aineopintojen kursseihin. Opinnot ovat yleisesti säilyneet tiivistä, oikeustieteellistä yleistutkintoa korostavina ja niiden sisällöt vahvistavat erityisesti oppimisen kognitiivista puolta (Pihlajamäki \& Lindblom-Ylänne 2001). Vaikka juristien perustutkinnossa on vuorovaikutuskoulutusta kohtuullisen niukasti, järjestävät muun muassa Asianajajaliitto ja oikeusministeriö täydennyskoulutusta aiheesta. Esimerkiksi syyttäjille suunnatussa koulutuksessa käytetään yleisesti simuloituja oikeudenkäyntejä (Streng 2011), mikä kuvastaa alakohtaisuuden huomioon ottamista.

Myös oikeustieteen opetuksen tutkimukset ovat harvassa (ks. Ervasti 2011; Pihlajamäki, Lindblom \& Ylänne 2001). Niissä on todettu, että tutkinnoissa pitäisi olla enemmän ongelmalähtöistä opetusta tukemassa ongelmanratkaisukykyä ja itsenäistä tiedon hankintaa. Tirrosen (2013) selvitys kertoo, että tutkinnot halutaan edelleen pitää tiiviinä yleistutkintoina, jotka jättävät substanssipuolen erikoistumisen työelämässä tapahtuvaksi. Opetukselliset uudistukset olisivat lähinnä opetuksen muotoon vaikuttavia. Valmistumisen jälkeinen tuomioistuinharjoittelu edustaa sen sijaan Dannelsin (2001) mukaista käsitystä oman alan oppimisesta ja tulevaan ammattiin tutustumisesta.

\section{Vuorovaikutusosaamisen arviointi oikeustieteen alalla}

Koska juristin tehtävät ovat monialaisia, vuorovaikutusosaamisen kriteereitä on vaikea määritellä. Sen lisäksi, että vuorovaikutuskoulutus on oikeustieteen perustutkinnossa harvinaista, myöskään osaamisen arviointi ei ole alalla systemaattista. Ainoastaan syyttäjän ja tuomarin tehtävissä vaadittavaa vuorovaikutusosaamista kartoittavissa tutkimuksissa arviointia on sivuttu (Välikoski 2004; Välikoski \& Ala-Kortesmaa 2013). Toisin kuin lääketieteen ja farmasian alalla, oikeustieteen alan peruskoulutuksessa ammatillista vuorovaikutusosaamista ei juurikaan arvioida eikä käytössä ole standardisoituja arviointimittareita. Täydennyskoulutuksessa arviointi on koulutuskohtaista.

\section{Yhteenveto}

Olemme tehneet näiden kolmen ammatin välillä tapausten välisen analyysin (ks. Miles \& Huberman 1994) alakohtaisen viestintäpedagogiikan neljän keskeisen periaatteen osalta. Analyysin tulokset on tiivistetty taulukkoon 1. 
Taulukko 1. Tiivistys alakohtaisen viestintäpedagogiikan periaatteiden ilmenemisestä lääkäreiden, farmaseuttien ja juristien vuorovaikutuskoulutuksessa.

\begin{tabular}{|c|c|c|c|}
\hline & Lääkärit & Farmaseutit & Juristit \\
\hline $\begin{array}{l}\text { Vuorovaiku- } \\
\text { tusosaami- } \\
\text { sen keskei- } \\
\text { set piirteet }\end{array}$ & $\begin{array}{l}\text { - jäsennetään useimmiten } \\
\text { lääkäri-potilasviestinnän } \\
\text { näkökulmasta vastaanoton } \\
\text { vaiheiden mukaan } \\
\text { - potilashaastatteluun } \\
\text { liittyvät tiedot ja suhde- } \\
\text { keskeiset vuorovaikutus- } \\
\text { taidot korostuvat, myös } \\
\text { tiimi- ja yhteistyötaidot } \\
\text { keskeisiä } \\
\text { - motivaatioon ja } \\
\text { asenteisiin liittyvä } \\
\text { ulottuvuus }\end{array}$ & $\begin{array}{l}\text { - jäsennetään useim- } \\
\text { miten vuorovaikutus- } \\
\text { taitoina } \\
\text { - keskeistä suhdekes- } \\
\text { keiset vuorovaikutus- } \\
\text { taidot: asiakaskeskei- } \\
\text { nen neuvonta, suhteen } \\
\text { luominen, kysyminen, } \\
\text { kuunteleminen ja } \\
\text { tiedon välittäminen } \\
\text { - myös yhteistyö } \\
\text { ja vaikuttaminen } \\
\text { keskeistä }\end{array}$ & $\begin{array}{l}\text { - jäsennetään useim- } \\
\text { miten ammatillisesta } \\
\text { roolista käsin } \\
\text { - keskeistä kognitii- } \\
\text { vinen ulottuvuus } \\
\text { vuorovaikutusosaa- } \\
\text { misessa: kuuntele- } \\
\text { minen, argumentointi } \\
\text { - suhdekeskeiset } \\
\text { vuorovaikutustaidot } \\
\text { osin korostuvat } \\
\text { - yhteistyö asiakkaan } \\
\text { ja kollegojen kanssa }\end{array}$ \\
\hline $\begin{array}{l}\text { Keskeiset } \\
\text { vuorovaiku- } \\
\text { tuskontekstit }\end{array}$ & $\begin{array}{l}\text { - tärkeitä konteksteja ovat } \\
\text { hoitotilanteet potilaiden } \\
\text { kanssa, esiintymistilanteet, } \\
\text { johtaminen ja työskentely } \\
\text { erilaisissa ryhmissä } \\
\text { - vuorovaikutuskontekstien } \\
\text { merkittävyys on sidoksissa } \\
\text { työtehtäviin, asemaan ja } \\
\text { uralla etenemiseen }\end{array}$ & $\begin{array}{l}\text { - tärkein konteksti } \\
\text { asiakaspalvelutilanne, } \\
\text { asiakasneuvonta } \\
\text { - lisäksi työyhteisön } \\
\text { sisäinen viestintä ja } \\
\text { terveydenhuollon } \\
\text { verkostoyhteistyö }\end{array}$ & $\begin{array}{l}\text { - tärkeitä konteksteja } \\
\text { oikeussalikäsittelyn } \\
\text { eri vaiheet, asiakas- } \\
\text { palvelu-tilanteet sekä } \\
\text { ammatillinen yhteistyö } \\
\text { - määrittyy työteh- } \\
\text { tävän, aseman tai } \\
\text { uralla etenemisen } \\
\text { perusteella }\end{array}$ \\
\hline $\begin{array}{l}\text { Vuorovaiku- } \\
\text { tusosaami- } \\
\text { sen oppimi- } \\
\text { sen tilanne- } \\
\text { sidonnai- } \\
\text { suus ja } \\
\text { sosiaalisuus }\end{array}$ & $\begin{array}{l}\text { - vuorovaikutuskoulutuksen } \\
\text { sitominen oikeisiin tai } \\
\text { simuloituihin tilanteisiin. } \\
\text { - koulutuksessa huomio } \\
\text { keskusteluun osallistujien } \\
\text { ja opettajien kesken } \\
\text { - opiskelijat ovat osa sai- } \\
\text { raalayhteisöä ja osallistuvat } \\
\text { potilaan hoitoon yhdessä } \\
\text { asiantuntijoiden kanssa }\end{array}$ & $\begin{array}{l}\text { - ammatissa toimivan } \\
\text { henkilöstön rooli } \\
\text { korostunut } \\
\text { - tärkeää työharjoitte- } \\
\text { lujakson hyödyntä- } \\
\text { minen } \\
\text { - koulutuksessa } \\
\text { huomio molemmin- } \\
\text { puolisen oppimisen } \\
\text { mahdollisuuteen }\end{array}$ & $\begin{array}{l}\text { - ammatillisen vuoro- } \\
\text { vaikutusosaamisen } \\
\text { oppiminen tapahtuu } \\
\text { pääasiassa perustut- } \\
\text { kinto-koulutuksen } \\
\text { jälkeen työssä } \\
\text { - täydennyskoulutuk- } \\
\text { sessa käytetään } \\
\text { simuloituja } \\
\text { oikeudenkäyntejä }\end{array}$ \\
\hline $\begin{array}{l}\text { Vuorovaiku- } \\
\text { tusosaami- } \\
\text { sen arviointi }\end{array}$ & $\begin{array}{l}\text { - runsaasti erilaisia } \\
\text { arviointimittareita } \\
\text { - tyypillistä on, että potilas- } \\
\text { haastatteluharjoituksen } \\
\text { onnistumista ja lääkärin } \\
\text { vuorovaikutustaitoja arvioi } \\
\text { ulkopuolinen havainnoija } \\
\text { standardoidun arviointi- } \\
\text { mittarin avulla } \\
\text { - käytössä vuorovaikutus- } \\
\text { taitojen näyttötentti }\end{array}$ & $\begin{array}{l}\text { - runsaasti asiakas- } \\
\text { neuvontaa kuvaavia } \\
\text { malleja ja jäsennyk- } \\
\text { siä, mutta arviointi- } \\
\text { käytänteet hajanaisia } \\
\text { - tyypillisesti käyte- } \\
\text { tään itsearviointia } \\
\text { - keskeistä moni- } \\
\text { puolinen arviointi- } \\
\text { kriteereiden } \\
\text { hyödyntäminen }\end{array}$ & $\begin{array}{l}\text { - peruskoulutuk- } \\
\text { sessa ammatillista } \\
\text { vuorovakkutusosaa- } \\
\text { mista ei arvioida } \\
\text { - ei standardoitua } \\
\text { arviointimittaria } \\
\text { - täydennyskoulu- } \\
\text { tuksessa arviointi } \\
\text { koulutuskohtaista }\end{array}$ \\
\hline
\end{tabular}


Vuorovaikutusosaamisen keskeiset piirteet: Analyysin pohjalta voidaan todeta, että kaikille ammateille yhteistä ovat suhdekeskeiset vuorovaikutustaidot eli viestinnän relationaalinen ulottuvuus, mutta erityisesti lääkärin ja farmaseutin ammateissa näitä korostetaan. Vastaavasti juristin ammatissa näkyvimmäksi nousee vuorovaikutusosaamisen kognitiivinen ulottuvuus. Kaikille ammateille yhteistä on myös yhteistyöhön liittyvä vuorovaikutusosaaminen.

Keskeiset vuorovaikutuskontekstit: Lääkärin ammatista on runsaasti tutkimustietoa, joka antaa monipuolisen ja jäsennetyn kuvan ammatin keskeisistä vuorovaikutuskonteksteista. Vastaavasti farmaseutin ja juristin kohdalla vuorovaikutuskonteksteja on tarkasteltu keskittyen muutamiin keskeisiin. Esimerkiksi lääkärin ammatissa työn luonne ja vastuu kuvataan laajemmin kuin farmaseutin ja juristin ammateissa. Farmaseutin ja juristin ammateissa asiakaspalvelu korostuu yhdeksi keskeiseksi vuorovaikutuskontekstiksi toisin kuin lääkärin ammatissa, jossa puhutaan hoitotilanteesta tai vastaanottotilanteesta. Juristin ja lääkärin ammatissa vuorovaikutuskontekstit määrittyvät työtehtävän, aseman tai uralla etenemisen perusteella. Kiteytetysti voidaan todeta, että ammattien vuorovaikutuskontekstit ovat erityyppisiä, mikä heijastuu eroihin myös keskeisen vuorovaikutusosaamisen painotuksissa.

Oppimisen tilannesidonnaisuus ja sosiaalisuus: Vuorovaikutusosaamisen tilannesidonnaisuuden suhteen ammatit eroavat selvästi toisistaan. Lääkärit ovat peruskoulutuksensa aikana jo osa työyhteisöä ja oppivat ammattikäytänteitä autenttisissa työtilanteissa osallistumalla potilaan hoitoon. Farmaseuttien koulutuksessa vuorovaikutusosaamisen oppiminen tapahtuu paljolti työharjoittelujaksoilla, joilla ammatissa toimivat farmaseutit ohjaavat opiskelijan oppimista. Sen sijaan juristin ammatillinen vuorovaikutusosaamisen oppiminen tapahtuu pääasiassa työssä perustutkintokoulutuksen jälkeen, jolloin erikoistutaan esimerkiksi tuomarin tehtäviin tai asianajajaksi. Miten ja missä vaiheessa opiskelija sosiaalistuu alan ammattilaiseksi, näyttäisi olevan selvästi erilainen prosessi vertailemillamme aloilla.

Vuorovaikutusosaamisen arviointi: Vuorovaikutusosaamisen arviointia on kehitetty erityisesti lääkäreiden ja farmaseuttien koulutuksessa. Lääkäreiden vuorovaikutusosaamisen arviointiin on luotu erilaisia standardisoituja arviointimittareita, ja farmaseuttien koulutuksessa puolestaan on käytössä runsaasti erilaisia asiakasneuvonnan malleja ja jäsennyksiä. Farmaseuttien koulutuksessa korostuu itsearviointi, kun lääkäreillä puolestaan tyypillistä on ulkopuolisen havainnoijan tekemä arviointi. Juristien koulutuksessa ei ole käytössä vastaavanlaisia vuorovaikutusosaamisen arviointikäytänteitä tai -välineitä.

\section{Pohdinta}

Farmaseutin, lääkärin ja juristin vuorovaikutusosaamisen ja -koulutuksen tarkastelu osoittaa, että kaikilla kolmella alalla vuorovaikutusosaamisen merkitys on 
suuri ja ammattilaisen vuorovaikutusosaaminen näyttää edistävän kansalaisen ja asiakkaan etua. Alojen rinnastaminen osoittaa, että tarvittavat vuorovaikutustaidot ovat erilaisia eri ammateissa. Voidaankin päätellä, että olisi lähes mahdotonta kehitellä puheviestinnän koulutusta, joka palvelisi parhaalla mahdollisella tavalla näiden kaikkien alojen ammattilaisten vuorovaikutusosaamisen erityistarpeita. Tämä puhuu alakohtaisen näkökulman puolesta. Toisaalta alojen vertailu osoittaa, ettei alakohtaisen pedagogiikan soveltaminen ole ongelmatonta.

Vertailujen pohjalta näyttää siltä, että alakohtainen viestintäpedagogiikka soveltuu parhaiten koulutukseen, joka tähtää selkeään työnkuvaan. Farmaseuttien ja lääkärien kohdalla voidaan melko täsmällisesti ennakoida, millaista työtä he tulevat tekemään. Juristikoulutus johtaa hyvin moniin erilaisiin työnkuviin, mikä asettaa alakohtaisen vuorovaikutuskoulutuksen näkökulman soveltamisen kyseenalaiseksi yliopistokoulutuksessa. Oikeustieteen alalla alakohtaisuuden näkökulma näyttääkin siirtyneen täydennyskoulutukseen, jolloin juristikoulutuksesta on jo eriydytty erilaisiin työtehtäviin ja kyseissä työssä vaadittava osaaminen voidaan täsmällisemmin määritellä. Tähän havaintoon kiteytyy niin koko alakohtaisen viestintäpedagogiikan peruskysymys kuin myös siihen osoitettu kritiikki: pitäisikö opettaa kaikkien alojen edustajille samanlaisia taitoja peruskursseilla vai antaa alakohtaista opetusta, joka pyrkii ottamaan huomioon alan erityisvaatimukset ja ominaisuudet? Meidän vertailumme näyttää, ettei asiaan ole yksiselitteistä vastausta, sillä tilanne vaihtelee alakohtaisesti. Näyttäisi siltä, että koulutuksen tähdätessä selkeästi asiantuntija-ammattiin, jonka työnkuva voidaan kohtuullisen selkeästi todentaa, alakohtaisuus tuntuisi olevan perusteltu vaihtoehto. Tässä näitä ammatteja ovat lääkäri ja farmaseutti, ja muita vastaavia voisivat olla esimerkiksi puheterapeutin tai journalistin ammatit. Sen sijaan juristien koulutuksessa alakohtaisuuden näkökulma on vaikeammin määriteltävissä, ja näin olisi myös esimerkiksi psykologin ammatissa. Toisen ääripään muodostaa yliopistokoulutus, joka saattaa johtaa mitä erilaisimpiin työtehtäviin. Useimmat humanistiset ja yhteiskuntatieteet ovat tällaisia aloja, joissa alakohtaisen vuorovaikutuskoulutuksen näkökulma ei olisi tarkoituksenmukainen (ks. Koivuoja \& Isotalus 2009).

Vertailumme tuo myös esiin, että tarkastelluilla aloilla opiskelija otetaan osaksi ammattialaansa eri tavoin ja eri vaiheissa. Tämä saattaa johtua koulutuksen rakenteisiin muodostuneista perinteistä. Toisaalta se saattaa heijastaa syvällisemmin alalla vallitsevaa ajattelutapaa siitä, missä vaiheessa opiskelijan on hyvä sosiaalistua alaansa. Alakohtaisen vuorovaikutuskoulutuksen kannalta tämä kytkeytyy kysymykseen, mihin opintojen vaiheeseen alakohtaisen vuorovaikutusosaamisen koulutus pitäisi sijoittaa. Tähän kysymykseen myös alakohtaisen viestintäpedagogiikan tutkimus voisi jatkossa paremmin pureutua.

Vuorovaikutuskoulutuksen alakohtaisuuden pohdinta johtaa myös kysymykseen koulutuksen kokonaistavoitteista. Alakohtaisuuden kriitikot, kuten Fleury (2005), ovat painottaneet, että alakohtaisuuden sijaan pitäisi opettaa 
yleisempää, eri viestintätilanteissa sovellettavaa vuorovaikutusosaamista. Tällöin voisi jopa puhua vuorovaikutusosaamisesta osana kansalaistaitoja. Mielestämme voisi sen sijaan ajatella vuorovaikutuskoulutuksen tavoitteiden suhteuttamista koulutuksen laajempiin tavoitteisiin. Yleissivistävän koulutuksen eli peruskoulun ja lukion tuleekin kehittää yleistä vuorovaikutusosaamista. Sen sijaan, jos koulutuksen kokonaistavoitteena on antaa tietty ammattitaito, vuorovaikutuskoulutuksen alakohtaisuuden suhteuttaminen siihen on perusteltua. Kärjistetysti ajatellen yleissivistävä koulutus on epäonnistunut tehtävässään, jos sen aikana kansalaisille ei kehity riittävän hyvät viestinnälliset kansalaistaidot, vaan niitä pitää paikata vielä ammattiin tähtäävässä koulutuksessa. Toisaalta alakohtaisessakaan puheviestinnän opetuksessa ei opita ainoastaan alasidonnaista vuorovaikutusta. Parhaimmillaan yleisyys ja alakohtaisuus asettuvat vuorovaikutuskoulutuksessa hedelmälliseen vuoropuheluun keskenään, jolloin yleisyys nostaa esille erilaiset kontekstit, osapuolet ja tieteenalat ja alakohtaisuus ankkuroituu tiettyyn kontekstiin, vuorovaikutussuhteeseen ja tieteenalaan (Fleury 2005). Tästä vuoropuhelusta nousee selkeä haaste: miten alakohtaista viestintäpedagogiikkaa tulisi teoreettisesti kehittää niin, että se pystyisi paremmin ottamaan huomioon koulutuksen yleiset tavoitteet. Yksi mahdollinen lähestymistapa on ajatella koulutuksen tavoitteet ja vuorovaikutuskoulutuksen alasidonnaisuus toisiinsa kytkeytyvänä jatkumona, jonka toisessa päässä on ammattiin tähtäävä ja toisessa laaja-alainen, monenlaisiin työtehtäviin valmentava koulutus. Edellisessä vuorovaikutuskoulutus olisi sidottu vahvasti alan erityistarpeisiin, ja jälkimmäisessä se olisi vähemmän alasidonnaista. Tällöin alakohtaisuus vuorovaikutuskoulutuksessa ei olisi yksi, erityinen koulutuksen muoto, vaan ennemminkin vaihteleva koulutuksen ominaisuus.

Tuloksemme kertovat, että alakohtaisessa viestintäpedagogiikassa alan käsite on ongelmallinen. Farmaseutin ja lääkärin ammatit tai alat ovat selkeät toisin kuin juristin ala, minkä vuoksi osuvampaa olisi puhua esimerkiksi syyttäjän tai tuomarin alasta. Esimerkiksi lääkäreiden kohdalla erikoistuminen, työtehtävät, uralla eteneminen ja työpaikka vaikuttavat siihen, millainen vuorovaikutusosaaminen on tärkeää ja millaiset vuorovaikutuskontekstit nousevat keskiöön. Sama pätee juristin ammattiin: täydennyskoulutuksessa tarpeet ovat erilaiset kuin perustutkintokoulutuksessa. Toisaalta lääkäreiden peruskoulutus on selvästi ammattiin tähtäävää ja siten alakohtaisen viestintäpedagogiikan soveltamista voidaan pitää perusteltuna. Alakohtaisen viestintäpedagogiikan teorian kehittämisessä olisi kuitenkin syytä ottaa alan käsite tarkemman määrittelyn kohteeksi ja pyrkiä selittämään, mitä alalla tämän viitekehyksen yhteydessä lopulta tarkoitetaan.

Alakohtaisen viestintäpedagogiikan yhtenä ytimenä on pidetty oppimisen tilannesidonnaisuutta ja sosiaalista luonnetta. Tähän liittyen on oltu huolissaan siitä, että se jättää vähemmälle opiskelijan omaan toimintaan liittyviä vaatimuksia tai oppimistilanteessa syntyvien kokemusten ja niiden reflektoinnin avulla 
tapahtuvaa oppimista (Hyvärinen 2011; Koponen 2012). On totta, että alakohtaisen viestintäpedagogiikan teoreettinen viitekehys ei sinänsä selitä, kuinka yksilö voi konstruoida tietoa (Koponen 2012), mutta tämä ei automaattisesti tarkoita yksilönäkökulman sivuuttamista. Onhan myös niin, että yksilön tavat konstruoida tietoa voidaan nähdä perustaltaan sosiaalisena toimintana, ammatillisissa käytänteissä ja vuorovaikutussuhteissa syntyneinä. Tällöin yksilöiden kokemus- ja konstruointitavat kuvastavat myös yhteisöllistä tapaa nähdä asioita ja niiden tarkasteleminen on alakohtaisen viestintäpedagogiikan hengen mukaista. Oppimisen näkökulmasta katsottuna tässä avautuu mahdollisuus nivoa yhteen kognitiivisen toiminnan tarkastelu ja sosiaalisessa yhteisössä tapahtuva oppiminen, mikä on keskeistä juuri puheviestinnän oppimisessa. Tätä ajattelua tukee esimerkiksi Mäkisen ja Annalan (2010) ajatus osaamisen holistisesta mallista, jossa sosio-kulttuuriseen näkemykseen oppimisesta integroituvat yksilön intellektuaaliset ja persoonalliset potentiaalit ja toiminta.

Toinen tilannesidonnaisuuteen liittynyt huoli on ollut traditioiden kritiikitön kierrättäminen. Esimerkiksi Koponen (2012) toteaa, että asiantuntijayhteisöön osallistumalla tapahtuvaan oppimiseen voi sisältyä se riski, että samat rutiinit ja totutut ajatusmallit siirtyvät tiedostamatta vanhemmilta nuoremmille ammattilaisille. Tutkimusten perusteella tiedetään, että opiskelijoilla on taipumus seurata kokeneemman työntekijän esimerkkiä ja ottaa siitä kritiikittömästi mallia (esim. Hyvärinen ym. 2005; Katajavuori 2005). Pelkästään nykykäytäntöjä vahvistava koulutus ei ole asiantuntijuuden kehittymisen näkökulmasta mielekästä, vaan käytetystä pedagogiikasta riippumatta vuorovaikutusosaamisen koulutuksessa pitää aina suhtautua kriittisesti nykyisiin käytäntöihin ja tarpeen vaatiessa pyrkiä uudistamaan myös työelämän vuorovaikutustapoja.

Tavoitteenamme oli tarkastella alakohtaista viestintäpedagogiikan viitekehystä kolmen ammatin näkökulmasta ja sitä kautta asettaa kysymyksiä viitekehyksen teoreettiselle kehittämiselle ja sen käytännölliselle soveltamiselle. Tarkastelumme tuotti uutta jäsennettyä ja vertailevaa tietoa vuorovaikutusosaamisen alakohtaisista erityispiirteistä sekä suuntaviivoja näkökulman teoreettiselle kehittelylle. Lisäksi sen pohjalta voitiin nostaa tärkeitä kysymyksiä itse alakohtaisuuden ymmärtämisestä ja määrittelystä sekä alakohtaisesta vuorovaikutuskoulutuksesta; millaista koulutuksen tulisi olla, kenelle suunnattuna, missä vaiheessa, miten toteutettuna ja miten arvioituna. Käytäntöä ajatellen kokoamamme vertailu tarjoaakin välineen, josta on hyötyä jäsennettäessä ja kehitettäessä vuorovaikutuskoulutusta myös muilla aloilla. Karkeudestaan huolimatta tarkastelumme kuvaa hyvin myös sitä, mikä merkitys vuorovaikutuskoulutuksella kyseisellä alalla on tai millaiseen perinteeseen se pohjautuu. Haasteena tarkastelussamme on ollut, että se perustuu aikaisempaan kirjallisuuteen. Eri alojen vuorovaikutuskoulutukseen liittyvä tutkimuskirjallisuus on hyvin erilaista, eri asioihin kohdistuvaa ja hankalasti toisiinsa verrattavissa. Lisäksi jollakin alalla aiheeseen liittyvästä kirjallisuudesta on runsauden pula ja toisella on vain muu- 
tamia varteenotettavia julkaisuja aiheesta. Vaikka toimme esille alakohtaiseen viestintäpedagogiikkaan liittyviä teoreettisia kysymyksiä, emme varsinaisesti koetelleet viitekehystä itseään. Alakohtaisen viestintäpedagogiikan viitekehys periaatteineen tulisikin jatkossa asettaa tutkimuksen kohteeksi.

\section{Kirjallisuus}

ACGME. 1999. Accreditation Council for Graduate Medical Education. The ACGME Outcome project. [Viitattu 27.10.2011]. Saatavilla wwwmuodossa: <URL: http://www.acgme.org/outcome/comp/compHome.asp>

Ala-Kortesmaa, S. \& Välikoski, T.-R. 2008. Käräjätuomareiden käsitykset kuuntelemisesta. Prologi, Puheviestinnän vuosikirja, 51-72.

Ala-Kortesmaa, S., Välikoski, T.-R. \& Isotalus, P. 2011. Listening concepts of Finnish and American legal professionals. Esitelmä. International Communication Associationin konferenssi 30.5.2011, Boston, MA, USA.

Ala-Kortesmaa, S. \& Isotalus, P. 2012. The effects of relational tensions on optimal listening in legal communication relationships. Esitelmä. International Communication Associationin konferenssi, 25.5.2012, Phoenix, AZ, USA.

Anderson, S. 2002. Profile of the professions. The state of world's pharmacy: A potrait of the pharmacy profession. Journal of Interprofessional Care 16 (4), 391-404.

Aspegren, K. 1999. BEME Guide No. 2: Teaching and learning communication skills in medicine - a review with quality grading of articles. Medical Teacher 21 (6), 563-570.

Brown, J. B., Steward, M. \& Ryan, B. L. 2003. Outcomes of patient-provider interaction. Teoksessa T. Thompson, A. M. Dorsey, K. I. Miller \& R. Parrot (toim.) Handbook of health communication. Mahwah: Lawrence Erlbaum, 141-161.

Bzowyckyj , A. S. \& Janke, K. K. 2013. A consensus definition and core competencies for being an advocate for pharmacy. American Journal of Pharmaceutical Education 77 (2), 24.

Bylund, C. L., D’Agostino, T. A., Ho, E. Y. \& Chewning, B. A. 2010. Improving clinical communication and promoting health through concordance-based patient education. Communication and Education 59 (3), 294-311.

Dannels, D. 2001. Time to speak up: a theoretical framework of situated pedagogy and practice for communication across the curriculum. Communication Education 50 (2), 144-158.

Darling, A. L. 2005. Public presentations in mechanical engineering and the discourse of technology. Communication Education 54 (1), 20-33.

Dickson, D. A., Hargie, O. D. W. \& Morrow, N. C. 1991. Communication skills training for health professionals. London: Chapman \& Hall.

Ervasti, K. 2011. Oikeustieteen opetuksen laatu opiskelijakyselyn valossa. Defensor Legis 6, 805. 
Fleury, A. 2005. Liberal education and communication against the disciplines. Communication Education 54 (1), 72-79.

Frank, J. R. (toim.) 2005. The CanMEDS 2005 physician competency framework. Better standards. Better physicians. Better care. Ottawa: The Royal College of Physicians and Surgeons of Canada.

General Medical Council. Tomorrow's Doctors 2009. [Viitattu 11.2.2013]. Saatavilla www-muodossa: <URL: http://www.gmc-uk.org/education/ undergraduate/tomorrows_doctors_2009.asp>

Gerlander, M. \& Isotalus, P. 2010. Professionaalisten viestintäsuhteiden ääriviivoja. Puhe ja kieli 30 (1), 3-19.

Haavisto, V. 2002. Court Work in Transition. An Activity-theoretical study of changing work practices in a Finnish District Court. Helsinki: Helsinki University Press.

Hargie, O. 2006. Skill in theory: Communication as skilled performance. Teoksessa O. Hargie (toim.) The handbook of communication skills. 3. painos. Lontoo: Routledge, 7-36.

Hargie, O., Boohan, M., McCoy, M. \& Murphy, P. 2010. Current trends in communication skills training in UK schools of medicine. Medical Teacher $32(5), 385-391$.

Hargie, O. D. W., Morrow, N. C. \& Woodman, C. 2000. Pharmacists' evaluation of key communication skills in practice. Patient Education and Counseling 39 (1), 61-70.

HE 82/1995 vp. Hallituksen esitys eduskunnalle rikosasioiden oikeudenkäyntimenettelyn uudistamista alioikeuksissa koskevaksi lainsäädännöksi.

Heathcote, W. W. 2000. Common Law. Microsoft $\AA$ Encarta ${ }^{\circledR}$ Online Encyclopedia. . [Viitattu 12.4.2013]. Saatavilla www-muodossa: <URL: https://autocww2.colorado.edu/ toldy2/E64ContentFiles/LawAndCourts/ CommonLaw.html>

Hullman, G. A. \& Daily, M. 2008. Evaluating physician communication competence scales: a replication and extencion. Communication Research Reports, 25 (4), 316-322.

Hyvärinen, M.-L. 2011. Alakohtainen vuorovaikutuskoulutus farmasiassa. Acta Universitatis Tamperensis 1604.

Hyvärinen, M.-L., Tanskanen, P., Katajavuori, N. \& Isotalus, P. 2012. Evaluating the use of criteria for assessing profession-specific communication skills in pharmacy. Studies in Higher Education 37 (3), 291-308.

International Pharmaceutical Federation (FIP). 2004. FIP statement of professional standards: Codes of ethics for pharmacists. Adopted in 1997 and approved in 2004. [Viitattu 15.4.2013]. Saatavilla www-muodossa: <URL: http://www.fip.org/www/uploads/database_file.php?id=209>

Jokisalo, E. 2005. Compliance and patient-perceived problems in the treatments of hypertension. Kuopion yliopiston julkaisuja A. Farmaseuttiset tieteet 82 . 
Kansanaho, H. 2005. Implementation of the principles of patient counselling into practice in Finnish community pharmacies. Division of Social Pharmacy. Faculty of Pharmacy. Helsinki: Univeristy of Helsinki.

Katajavuori, N. 2005. Vangittu tieto vapaaksi - asiantuntijuus ja sen kehittyminen farmasiassa. Helsinki: Helsingin yliopisto.

Katajavuori, N., Valtonen, S., Pietilä, K., Pekkonen, O., Lindblom-Ylänne, S. \& Airaksinen, M. 2002. Myths behind patient counselling: a patient counselling study of non-prescription medicines in Finland. Journal of Social \& Administrative Pharmacy 19 (4), 129-136.

Kimberlin, C. L. 2006. Communicating with patiens: skills assessment in US colleges of pharmacy. American Journal of Pharmaceutical Education 70, article 67.

Koivuoja, H. \& Isotalus, P. 2009. Yliopistosta valmistuneiden näkemyksiä työelämän puheviestinnästä ja saamastaan puheviestinnän. Teoksessa M. Almonkari \& P. Isotalus (toim.) Akateeminen puheviestintä. Kuinka opettaa puheviestintää yliopisto-opiskelijoille? Helsinki: Finn Lectura, 138-165.

Koponen, J. 2012. Kokemukselliset oppimismenetelmät lääketieteen opiskelijoiden vuorovaikutuskoulutuksessa. Acta Universitatis Tamperensis 1734.

Kurtz, S. M., Silverman, J. \& Draper, J. 2005. Teaching and learning communication skills in medicine. 2. painos. Oxford: Radcliffe Publishing.

Lahnajärvi, L. 2006. Reseptien uusiminen. Miten pitkäaikaislääkitystä toteutetaan terveyskeskuksissa? Kuopion yliopiston julkaisuja A. Farmaseuttiset tieteet 93.

Laki potilaan asemasta ja oikeuksista 785/1992.

Laki syyttäjälaitoksesta 439/2011.

Lave, J. \& Wenger, E. 1991. Situated learning. Legitimate peripheral participation. Cambridge: Cambridge University Press.

Lingard, L., Schryer, C. F., Garwood, K. \& Spafford, M. M. 2003. 'Talking the talk': school and workplace genre tension in clerkship case presentations. Medical Education 37 (7), 612-620.

Lääkärikysely. 2009. Helsinki: Suomen lääkäriliitto.

Miles, M. B. \& Huberman, A. M. 1994. Qualitative data analysis. An expanded sourcebook. 2. painos. Thousand Oaks: Sage.

Miller, C.R. 1984. Genre as social action. Quarterly Journal of Speech 70, 151-167.

Morton, J. \& O'Brien, D. 2005. Selling your design: oral communication pedagogy in design education. Communication Education 54 (1), 6-19.

Mäkinen, M. \& Annala, J. 2010. Osaamisperustaisen opetussuunnitelman monet merkitykset korkeakoulutuksessa. Kasvatus ja Aika 4 (4), 41-61.

Palsson, R., Kellett, J., Lindgren, S., Merino, J., Semple, C. \& Sereni, D. 2007. Core competencies of the European internist: A discussion paper. European Journal of Internal Medicine 18, 104-108.

Pihlajamäki, H. \& Lindblom-Ylänne, S. 2001. Langdellin ja Deweyn ongelmat: oikeustieteen opetuksen uudet haasteet. Oikeus 2001/2, 169183. 
Puumalainen, I. 2005. Development of instruments to measure the quality of patient couselling. Kuopio University Publications A. Pharmaceutical Sciences 83.

Pyörälä, E. \& Hietanen, P. 2011. Vuorovaikutustaidot osana lääkärin ammatillista kehittymistä. Suomen Lääkärilehti 66 (6), 469-473.

Ramburuth, P. \& Mladenovic, R. 2004. Exploring the relationship between student's orientations to learning, the structure of students' learning outcomes and subsequent academic performance. Accounting Education: An International Journal 13 (4), 507-527.

Saarni, S. 2005. Lääkärin etiikka. 6. painos. Helsinki: Suomen Lääkäriliitto.

Saha, H. 2003. Lääkäri ja potilas. Teoksessa P. Mustajoki, R. Pelkonen \& T. Sane (toim.) Potilaan tutkiminen. Helsinki: Duodecim, 7-18.

Shah, B. \& Chewning, B. 2006. Conceptualizing and measuring pharmacistpatient communication: a review of published studies. Research in Social and Administrative Pharmacy 2 (2), 153-185.

Sosiaali- ja terveysministeriö. 2011. Lääkepolitiikka 2020. [Viitattu 15.4.2013] Sosiaali- ja terveysministeriön julkaisuja 2011:2. Saatavana www-muodossa: <URL: http://www.stm.fi/c/document_library/get_file?fol derId $=2765155 \&$ name $=$ DLFE-14405.pdf $>$

Smith, L. F. 1999. The undergraduate legal communication course. American Communication Journal 2 (2), 1.

Speicker, S. \& Worthington, D. L. 2008. Explorations of juror reasoning: the influence of attorney opening statement/closing argument organizational strategy. Communication Law Review 8, 52-63.

Spitzberg, B. H. \& Cupach, W. R. 2002. Interpersonal skills. Teoksessa M. L. Knapp \& J. A. Daly (toim.) Handbook of interpersonal communication. 3. painos. Lontoo: Sage, 564-611.

Spitzberg, B. H. \& Dillard, J. P. 2002. Social skills and communication. Teoksessa M. Allen, R. W. Preiss, B. M. Gayle \& N. Burrell (toim.) Interpersonal communication research: advances through meta-analysis. Mahwah: Lawrence Erlbaum, 89-107.

Street, R. L. Jr. 2003. Interpersonal communication skills in health care contexts. Teoksessa J. O. Greene \& B. R. Burleson (toim.) Handbook of communication and social interaction skills. Mahwah: Lawrence Erlbaum, 909-933.

Streng, V. 2011. Syyttäjät puheviestinnän ammattilaisina. Akkusastoori 1, $10-11$.

Suomen Apteekkariliitto 2011. Apteekit tehostavat itsehoitolääkkeitä ostavien neuvontaa. [Viitattu 15.4.2013]. Saatavilla www-muodossa: <URL: http:// www.apteekkariliitto.fi/fi/media/tiedotteet/2011/apteekit-tehostavatitsehoitolaakkeita-ostavien-neuvontaa.html>

Suomen Apteekkariliitto ja Suomen Farmasialiitto 1998. Apteekkitoiminnan eettiset ohjeet. . [Viitattu 10.4.2013]. Saatavilla www-muodossa: <URL: http://www.apteekkariliitto.fi/asiakkaille/eettiset-ohjeet.html>

Tirronen, J. 2013. Oikeustieteellisten tutkintojen kehittäminen ja työmarkkinoiden tarpeet. Oikeustieteiden laitos, Itäsuomen yliopisto. 
United States Pharmacopeia. 2002. Medication counselling behaviour guidelines. . [Viitattu 15.1.2002]. Saatavilla www-muodossa: <URL: http:// www.usp.org>

Vainio, K. 2004. Lääkeneuvonnan kehittäminen suomalaisissa apteekeissa. Kuopion yliopiston julkaisuja A. Farmaseuttiset tieteet 78 .

Valkonen, T. 2003. Puheviestintätaitojen arviointi. Näkökulmia lukiolaisten esiintymis- ja ryhmätaitoihin. Jyväskylä Studies in Humanities 7.

Vrchota, D. 2011. Communication in the disciplines: interpersonal communication in dietetics. Communication Education 60 (2), 210-230.

Välikoski, T.-R. 2000. Todistajana rikosoikeudenkäynnissä. Selvitys rikosoikeudenkäynnin viestinnällisestä luonteesta todistajan näkökulmasta. Tampereen yliopisto. Puheopin laitos. Raportteja 1/2000.

Välikoski, T.-.R 2004. The criminal trial as a speech communication situation. Acta Universitatis Tamperensis 1011.

Välikoski, T.-R. \& Ala-Kortesmaa, S. 2013. The communicational orientations of prosecutors in a criminal trial. Esitelmä. National Communication Association (NCA) konferenssi, 23.11.2013, Washington D.C., USA.

Wallman, A., Vaudan, C. \& Kälvemark Sporrong, S. 2013. Communications training in pharmacy education, 1995-2010. American Journal of Pharmaceutical Education 77 (2), 36.

World Health Organization 2011. Joint FIP/WHO guidelines on good pharmacy practice: standards for quality of pharmacy services. WHO Technical Report Series, No. 961, Geneva: World Health Organization. 